\title{
Challenges for the Romanian Public Pensions System in the Current Economic and Financial Crisis
}

\author{
Anca-Ştefania Sava, University of Iasi, Romania
}

\begin{abstract}
This paper aims to address the challenges for the Romanian public pensions system in the current economic and financial crisis. Firstly, are presented the defining indicators of the Romanian public pension system, such as number of pensioners, the number of taxpayers, the dependency ratio pensioners/contributors, public pension expenditure as a percentage of GDP, etc. The article illustrates the challenges regarding the sustainability of the pension system to the aging population and the main predictions of specialized financial institutions on public pension expenditure for the next period. It also presents the current abuses of public pension system and the measures taken by the Romanian authorities to reform it.
\end{abstract}

\section{Keywords}

Romanian public pension system, public pension expenditure, economic and financial crisis

JEL Code: H55, G23, O47

\section{Introduction}

The financial crisis has rapidly turned into an economic crisis with major implications for all public programs, including pension systems. Rising unemployment and difficulties in collecting revenues for the state budget, due to financial and economic crisis, has affected the social security schemes, pension funds and other sources of income of older people across the globe.

Given this context, governments must deal with budget deficits that will result from maintaining or increasing the benefits of social programs. According to Hinz et al. (2009), combined fiscal deficit of the pension systems could range from less than $1 \%$ of GDP, if the crisis proves to be moderate, and recovery is rapid, up to $13 \%$ of GDP otherwise. Current deficits involve expansion of public debt, which can spur the economic recovery, but at the same time, transfer some of the burden of adjustment to future generations. Also, according to a recent review of World Bank estimates (2009), after consulting measures to reform the pension law in Romania, in 2050, the deficit created by spending on pensions in GDP, by keeping the current system, will reach $12 \%$.

Hit by the global crisis, many states have made changes in public pension schemes and adjusted the operating parameters. Such measures are aimed at: increasing the statutory retirement age (the case of Germany, Australia, Austria, Belgium, Denmark, Czech Republic etc.), increased mandatory minimum period of contribution (France), changing how pensions are indexed to future reduced increases (the case of Hungary), reducing pensions in payment (Latvia, Hungary). 
According to some studies ${ }^{1}$, state pensions are much less sustainable than systems based on capitalization and private management. This we can find also for Romania and the new draft law on pesions envisages reforming public pension system.

\section{Analysis Indicators of the Romanian Public Pension System}

A factor that carries impact on the public pension system is the aging population, further increasing the living standards of the last century, the professional development of individuals, but also the development and progress of medicine.

The population of Romania is in a process of reduction and accelerated aging: from 23.2 million inhabitants (1990) to 21.3 million inhabitants (2010). Under scenarios of the International Monetary Fund, United Nations, European Union, World Bank, 2050 will be reached on 16-17 million people or 13.3 million people (most pessimistic scenario, EBRD, 2008).

The current situation of the pension budget was generated by a number of decisions taken by those in government after 1989. At that time, Romania had 8 million employees and 2.6 million of pensioners, with an additional one million of retired farmers. The dependency ratio, calculated as the ratio between the number of employees contributing to social security state and the number of beneficiaries, was at the time, comfortable, of 3.4 employees to one retired and the pension fund had a surplus of 500 million USD.

In the next two years, the number of pensioners increased to 3.2 million people because of the Decree-Law no. 60, given in March 1990, which sent the pension in a few months, over 500,000 employees, as permitted early retirement with four years for sickness and with two years earlier for the normal early retirement. Thus, the dependency ratio became 2.1 employees / 1 retired due to being represented by the decision to reduce the retirement age in 1990 , for women at 53 years and for men at 58 years.

During 1992-1996, under the government Vacaroiu, 500,000 other employees have become pensioners, many of them being unemployed after the first privatizations. Also in 1993, were taken to the public fund other 120,000 retirees, resulting from the bankruptcy of cooperatives, as also the pensioners from the creation funds, artists etc. At that time, 1.6 employees sustained one pensioner.

In 1996, the pension fund recorded a deficit of $0.23 \%$ of GDP and needed small loans from the State Treasury to cover losses.

Moreover, the massive retirement between 1990 and 1998 have served to mask unemployment privatization. These realities have led to the preparation of a draft pension law in 1998 which came into force in 2001 after 2 years of debate in Parliament. Law has been distorted by the 57 subsequent regulations introduced by the privileged classes. Special pensions, for example, establishing a preferential retirement judiciary, parliamentarians, ambassadors and civil pilots, were introduced one by one, by parliamentarians, from 2003 to 2008. The number of people with special retirement came in 2009 to about 200,000 .

The critical point was the year 2001, when the number of pensioners from state insurance budget ( 4.5 million, without former farmers) exceeded the number of employees in the economy (4.4 million), the dependency ratio being 0.9 to 1 retired employees.

Further, in the period 2004-2008, pension expenditure reached 13 billion USD ( $€ 9.2$ billion) because the pension point value increased from 265.2 lei, as it was in January 2004, to 697.5 lei, in October 2008.

According to Labor Ministry statistics, the total number of pensioners of the state social security system, including paying farmers in 2009 were 5.54 million people, while the total number of contributors to public pension system did not exceed, at that time 5.65 million people, leading to a dependency ratio for the public pension system of 0.98 for retired to 1

\footnotetext{
${ }^{1}$ Federacion Internacional de Administradoras de Fondos De Pensiones (2009), The impact on workers
} of the parametric changes in the PAYGO programs, pp.5-6 
taxpayer. In 2009, total annual pension expenditure in Romania were about 39 billion lei, the largest budget expenditure category, its share in gross domestic product being $8 \%$. Thus, the pension fund budget deficit was about 1.5 billion euros (about 2 billion dollars), while that for 2010 is estimated at 1.7 billion euros.

One of social measures adopted by the Romanian Government in 2009 was indexing pensions by $3 \%$ on April 1 and 2\% from October 1 this year. The value of the pension point has become currently 732.8 lei.

The public pension system in Romania, as also from other countries, have felt the impact of these demographic changes. According to European Commission estimates, the number of pensioners in the public pension system will rise to $6,736,000$ in the year 2050, respectively $6,445,000$ pensioners in the year 2060, the growth rate from 2009 to 2060 being $16.85 \%$. Concerning taxpayers, the number is estimated to decline from a level of 6,348,000 contributors to the year 2010, to 5,689,000 contributors in 2050 and respectively, in 2060 to $5,297,000$ contributors, the rate of decrease in the period $2010-2060$ being $16.56 \%$.

According to UN statistics, the evolution of old age dependency ratio by the year 2050, will increase by more than 2 times: from $21 \%$ in 2005 to $49 \%$ in 2050 , when old age dependency ratio of 65 years and over, compared to $15-64$ years; from $23.6 \%$ in 2005 to $56.6 \%$ in 2050 , for old age dependency ratio of 65 years and over compared to the population of 20 to 64 years ${ }^{2}$. An increase in the dependency rate indicates a situation where an increasing number of potential beneficiaries of health and pension system (especially those aged 65 or over) are supported by a relatively small number of potential contributors.

The process of population aging is doubled by another, the net migration. According to Population Division of the Department of Economic and Social Policy of the United Nations Secretariat statistics, in the period 2010-2015, net migration per year will be -20, and in 2015 will be 1.

Also, the long-term sustainability report of the European Commission, reports that agerelated expenditure will increase in the EU, according to forecasts, by about $43 / 4$ percentage points of GDP on average until 2060 and by over 5 percentage points in the euro area - in particular because expenditure on pensions, health costs and those for long-term care ${ }^{3}$. For Romania, as also to Luxembourg, Greece, Slovenia, Cyprus, Malta, Netherlands, Spain and Ireland, according to European Commission forecasts, growth of age-related public spending will be fairly significant, with 7 percentage points or even more. However, pension reforms adopted in many Member States produce positive results in terms of sustainability of public finances. Almost all Member States have tightened the conditions for eligibility for public pensions, mainly by increasing the retirement age and restricting access to early retirement schemes.

European Commission Report shows that Romania has a sustainability deficit of $9.1 \%$ of GDP and must adjust, long-term budgetary executions this percentage to reach a situation in which public finances are sustainable and healthy. Most of this deficit sustainability (7.4 percent from 9.1 percent of GDP) comes from the increasing costs of state pensions. In the background event demographic phenomena, that of aging, reduce fertility and population reduction, with negative effects on public budgets, European Commission estimates that the level of public spending on pensions will increase the EU average of $10.2 \%$ of GDP in the 2010 , to $12.5 \%$ in 2060 .

In 2009 the Romanian state has spent about 48 billion lei, representing 9.5\% of GDP and $31 \%$ of the revenues of the country, which is justified as follows: 40.4 billion lei for public system pensions, 3, 2 billion lei for pensions to farmers, over 3.7 billion lei for special military pensions for police and special services and over 608 million lei for airmen pension, magistrates, parliamentarians, diplomats etc.

\footnotetext{
${ }^{2}$ Fiț, S. (2009), Perspectivele sistemului românesc de pensii, Editura Mirton, Timişoara, pp.159-166

${ }^{3}$ Comisia Comunităților Europene (2009), Raport privind imbătrânirea popula $\square$ iei, Bruxelles, p.4
} 
State social security budget deficit total was about $€ 1.74$ billion (7.36 billion lei) in 2009 . Revenues from pay state social insurance contributions were nearly 33 billion lei in 2009, $2.36 \%$ higher than in 2008 , while expenditure on contributory pension scheme, without farmers' pensions and special pensions were 40.4 billion lei in 2009, up 19.9\% from 2008 .

According to the Romanian government, in 2009, state budget lent pension budget of $€ 1.5$ billion. Funds for pensions for 2010 are on the sum of 39.6 billion lei, of which $€ 1.7$ billion euros is the money contributors pay as taxes to the state budget. Pension costs for 2010 will be $7.36 \%$ of GDP (538 billion lei). Our country is among the states with the unsustainable public pension budgets of the EU, the estimated share of GDP spent on pensions of state will have an upward trend from $8.4 \%$ for 2010 , to $15.4 \%$ in 2060 . It is estimated that after more than 50 years, Romania will be the 5th place at European level after Greece, Luxembourg, Slovenia and Cyprus, for the largest share of GDP spent on pensions.

\section{Policies to Reform the Public Pension System in Romania}

According to demographic forecasts, the true crisis is on the starting point. It is very important that measures taken now to cover long-term objectives. Some recommendations from international financial institutions are: indexing pensions to inflation, increasing the retirement age and equality for men and women, and reduce early retirement.

The decision to index pensions to inflation during the crisis is to better protect pensioners in the short term by maintaining purchasing power, but at the same time, contribute to longterm fiscal sustainability of the pension system. As regards the second objective, the retirement age, it is known that most OECD countries amounted already the retirement age for men and women up to 65 or beyond, while most ECA countries continue to enable men to retire earlier than 65 years and continue to allow women to retire at ages even lower than men's . Average age is even lower than the statutory retirement age, with half or more of retirees younger than November withdraw legal retirement age because of early retirement privileges for many pre-transitional occupations. While life expectancy for male is significantly lower than in Western Europe, the expected duration of benefits is longer for men and women even more than in Western Europe.

The current Romanian public pension system faces many abuses, which the new pensions law attempts to eliminate, such as:

-Massive increase disability retirement, as evidenced by the increase of 50\% from 600,000 persons in 2001 to 900,000 in 2009 , because of fraudulently receiving an invalidity pension to other persons not meeting the necessary health conditions.

-Tripling the number of annual early retirement, in 2009 leading to the 115,000 early retirement in part.

Of course, there is a risk that we will have fewer taxpayers to fund pensions and will no longer be paid pensions in the future. The new law proposes to introduce a mechanism to discipline this practice of early retirement and not to encourage this mechanism. Each person is entitled to take an early retirement, only that there is a small penalty. It is currently $30 \%$ of retirement, but the new law provides for an increase to $45 \%$. For example, if a woman retirement age is today 58 years and 9 months, she can retire early at 53, but in the period from 53 to 58 years, the pension will be less with $30 \%$. In other countries, such as Germany, the penalty is maintained throughout the pension, just to dampen this mechanism.

-A disagreement between the smallest and largest public pension in Romania

The existence of special systems of public pensions which introduced a number of privileges and unequal treatment for some occupational categories has created a huge difference between the lowest pensions (350 lei) and the largest public pension (37,000 lei), more than 100 times, a ratio of 1 to 100 . This suggests an unfair system that can not continue, as are necessary money from the state budget to other areas, such as health, education, infrastructure, and at the same time, it is necessary to have a budget of pensions on a selfsustaining based, according to the contributivity principle. 
The new law brings into question the contributivity principle, which is considered by some as a correct principle, a healthy, equitable one, ensuring sustainability of the pension system in Romania and according to this principle, if you make a greater contribution during the course of employment to pension budget, you will receive a larger pension, and on the opposite, if you have a lower contribution, the pension will be smaller.

Implementing this principle means eliminating the privileges and discrimination which currently exists in the actual pensions system. Of 5,800,000 pensioners, about 180,000 receive special pensions and only for $15 \%$, which are not based on the contributivity pension principle, the pension will decrease, while those with a military pension up to 30 million lei will not be affected. Special pension declines to those where pension was determined to be $80 \%$ of revenues a person had in the last month of activity at work. For example, if a person has contributed to a pension of 25 million lei, but last month the revenue was 100 million lei, they received a pension of 80 million lei ( $80 \%$ of 100 million lei).

-actual average retirement age

By law, the retirement age should be today 58 years and 9 months for women and 63 years and 9 months for men. The actual age that we have in fact is 54 years and 7 months. According to the new law, the retirement age for both women and men will be 65 years.

According to Pensions at a Glance report (2009), for countries like Czech Republic, Greece, Hungary and Turkey, eligible retirement age would increase during the next period to 65 years. From 1995 to 2005 , in 15 countries increased the retirement age, is the case of Austria (60 years and for the future, 65 years, between 2024 and 2033), Belgium (from 64 to 65 years in 2009), Republic Czech (increased with 2, respectively with 4 months in each year since 1996 in order to increase the retirement age in 2030 to 65 years for men and for single women and for those with a child between 62 and 64 years for those with more of a child), Italy (61 to 63 years between 2010 and 2013), etc.

Also, in the last 5 years, some states have planned to increase the retirement age over 65 years, such as Australia and Germany to 67 years and Britain in 68 years. Over the years, according to an analysis of the OECD in 1958 and until the year 1999, retirement ages have fallen, and later to boost. For men, the retirement age fell by 2.5 years between 1958 and 1999 to below 62 years, the OECD average, while women decreased by just 1.5 years, averaging 60.5 in 1999. Since 1999 and until now, the retirement age for both sexes showed increases of about 2 years.

The financial impact for the consolidated budget of implementing the law on pensions, on both short and long term (year 2020) will consist of ${ }^{4}$ : reducing pension costs by cca.784 million lei in 2010 and about 1.459 million lei in 2020, reducing the consolidated public budget expenditures with cca.2761 million lei in 2010 and about 24.119 million lei in 2020, increasing public budget income with cca.152 million lei in 2010 and about 2.626 million lei in 2020 .

\section{Conclusions}

The financial crisis has significantly affected the pension systems around the world, signaling the governments to respond as promptly to the increase pension deficits, which are facing today.

While some public European pension programs date back in the late 19th century, current schemes are the result of changes imposed largely after World War II. Based on various studies conducted by international financial institutions, aging and also net migration, are factors causing concerns to governments based on the „Pay as you go" system, as a consequence of the increase budget expenditures by public pensions.

To get an insight into the public pension system in Romania was made an analysis of key figures (the number of pensioners, the number of taxpayers, the dependency ratio of this

${ }^{4}$ Expunerea de motive privind Legea privind sistemul unitar de pensii publice, februarie 2010, p.7 
indicators, public pension expenditure in GDP, etc.) since 1989 till now. There have seen some cases the sustainability of current difficulties: decrees that allowed too low retirement age (in 1990, women retired at 53 years and men at 58 years), decisions that facilitated the massive retirement in 1990 and 1998, the goal being to disguise unemployment privatization, loans from the pension fund to cover budget holes, increasing funded retirees to the state with those resulting from failing industries (1993), the pension emergences for special categories (MPs, magistrates, officers).

On the other hand, were presented the abuses faced by the Romanian public pension system:, such as: the massive increase for cases of disability retirement, triple of the annual number of early retirement, disagreement between the lowest and most large pension public pension system and the actual average retirement age under the legal.

The new pension law aims to introduce a mechanism to discipline early retirement system, retirement check sickness, to increase the average age retirement at 65 years for women and men, to eliminate all discrimination in the system, to reduce pensions set at a high level, and also to contribute to the unification of public pension system.

I think that for the future, a prudent way of ensuring those who currently contribute to the state social insurance budget that will benefit from a pension when they reach the retirement age, it to combine the public financing system „Pay as you go" with the private funds, being known the fact that diversity of funding pension sources provides security in old age.

\section{Acknowledgements}

I am grateful to "Alexandru Ioan Cuza" University of Iasi, for financial support of this article, as beneficiary of a grant POSDRU/88/1.5/S/47646, named "Studii doctorale: portal spre o carieră de excelență în cercetare şi societatea cunoaşterii", cofinanced from the European Social Fund, within the Sectoral Operational Programme Human Resources Development 2007-2013, the project implementation period being 36 months, from March 1, 2010, until February 28, 2013.

\section{References}

1. European Commission and Economic Policy Committee (2009), The 2009 Ageing Report: economic and budgetary projections for the EU-27 Member States (2008-2060), Brussels, No 1

2. Divizia Populație a Departamentului de Politici Economice şi Sociale a Secretariatului Naţiunilor Unite (2009), Perspective privind populația lumii: versiunea 2008, http://esa.un.org/unpp

3. Expunerea de motive privind Legea privind sistemul unitar de pensii publice, februarie 2010

4. Federacion Internacional de Administradoras de Fondos De Pensiones (2009), The impact on workers of the parametric changes in the PAYGO programs

5. Fit, Simona (2009), Perspectivele sistemului românesc de pensii, Editura Mirton, Timisoara

6. Holzmann, Robert. (2009), Aging Population, Pension Funds, and Financial Markets: Regional

Perspectives and Global Challenges for Central, Eastern and Southern Europe, Washington, DC

7. OECD (2009), Pensions at a glance 2009: Retirement-income systems in OECD countries, Paris

8. http://www.mmuncii.ro/

9. http://epp.eurostat.ec.europa.eu/portal/page/portal/eurostat/home/ 